\title{
Review of 15 Years of Research on Sediment Heavy Metal Contents and Sediment Nutrient Release in Inland Aquatic Ecosystems, Turkey
}

\author{
Serap Pulatsü, Akasya Topçu* \\ Department of Aquaculture and Fisheries Engineering, Agricultural Faculty, Ankara University, Ankara, \\ Turkey \\ Email: spulatsu@agri.ankara.edu.tr, ${ }^{*}$ atopcu@.ankara.edu.tr
}

Received 5 January 2015; accepted 26 January 2015; published 30 January 2015

Copyright (C) 2015 by authors and Scientific Research Publishing Inc.

This work is licensed under the Creative Commons Attribution International License (CC BY). http://creativecommons.org/licenses/by/4.0/

(c) (i) Open Access

\begin{abstract}
Turkey's inland water ecosystem consists of 33 rivers (177.714 miles), 200 natural lakes (906.118 ha), 159 reservoirs ( $342.377 \mathrm{ha})$ and 750 ponds $(15.500 \mathrm{ha})$. Sedimentological studies conducted on inland water ecosystems during the last 15 years in Turkey can be categorized into two main topics. The first group of studies is concerned with heavy metal levels in sediment, with especial reference to the interaction between water, sediment and aquatic organisms. Additionally, the studies in question deal with the potential impacts of heavy metal concentrations on the ecosystem. The second group of studies is concerned with the role of eutrophication in the sediment as a result of serious contamination of inland water ecosystems. It is known that the sediment can directly influence the nutrient level in standing inland waters such as lakes and ponds by way of internal nutrient loading. In this context, studies regarding sediment, overlying water, sediment pore water and nutrient release from the sediment should be emphasized as these are important steps with respect to the eutrophication process. By keeping these studies in mind, the researcher in this study compiled and analyzed studies dealing with inland water ecosystems with differing nutrient levels and uses, including for drinking water, in Turkey's drainage basins. In addition, field and laboratory studies regarding nutrient release from sediment into Turkey's inland water ecosystems were evaluated in light of lake management practices.
\end{abstract}

\section{Keywords}

Sediment, Heavy Metal, Nutrient Release, Inland Water

\footnotetext{
${ }^{*}$ Corresponding author.
}

How to cite this paper: Pulatsü, S. and Topçu, A. (2015) Review of 15 Years of Research on Sediment Heavy Metal Contents and Sediment Nutrient Release in Inland Aquatic Ecosystems, Turkey. Journal of Water Resource and Protection, 7, 85-100. http://dx.doi.org/10.4236/jwarp.2015.72007 


\section{Research Regarding Sediment Heavy Metal Content in Inland Aquatic Ecosystems}

The concentrations of heavy metals in receiving environments have both natural causes, such as sea-bed volcanic activity, atmospheric convection, rivers or erosion, and man-made causes, such as mining, the rapid increase of treatment and refining systems, the excessive use of fossil fuels, and the use of metallic products in agriculture (like arsenic pesticides). Of the heavy metals that are transported into the water, one portion is diffused in the water and the other portion forms solid compounds with carbonate, sulfate and sulfur, sinks to the bottom, and is accumulated in the sediment [1]. Accordingly, the sediment forms a trap for heavy metals, and thus, concentrations of heavy metals in the sediment can be several orders of magnitude greater than in the overlying water. Metals found in the sediment directly threaten detrital and deposit-feeding benthic organisms, and could possibly be a long-term source of contamination higher up the food chain [2].

Fish can take in heavy metals through respiration (through the gills or the skin), adsorption to body surfaces or feeding. The intake of heavy metals and their accumulation in the organisms in aquatic ecosystems are affected by several factors, such as differences in the amount of metals entering the environment, the condition of the organism and the physical and chemical properties (temperature, salinity, $\mathrm{pH}$ and dissolved oxygen) of the aquatic environment in which the organisms are found.

Quantitative sediment quality guidelines (SQG) exist for freshwater ecosystems, and these provide a reliable benchmark for assessing sediment quality in freshwater ecosystems. The threshold effect level (TEL) and the probable effect concentrations (PEC) for different sediment contaminants in freshwater ecosystems were determined by [3]. TEL corresponds to the concentration of a contaminant below which harmful effects on benthic organisms are expected to occur only rarely, and PEC represents the concentration above which harmful effects on aquatic biota are expected to occur frequently [3].

For this review, studies on the interaction between water, sediment and aquatic organisms conducted over the past 15 years in five different types of aquatic ecosystem in Turkey (lakes, reservoirs, wetlands, rivers and streams) were compiled, and the surface sediment concentrations of arsenic, cadmium, chromium, copper, lead, mercury, nickel and zinc reported by these studies were compared with [3]'s threshold effect level (TEL) and probable effect concentration (PEC) values for these metals. Additionally, studies performed under field and laboratory conditions regarding the release of nutrients from the sediment in Turkey's inland aquatic ecosystems were evaluated in the light of lake management practices.

\subsection{Lakes}

Some heavy metal concentrations in sediment from different lakes in Turkey are shown in Table 1.

Beyşehir Lake is a conservation area located in southwestern Turkey used for irrigation and drinking water. The main factors contributing to its contamination are industrialization and urbanization. During the spring of 2001, water, sediment, plankton and fish samples were collected from three different stations in the lake. The order of heavy metals accumulation in the food chain was determined as water $>$ plankton $>$ sediment $>$ fish tissues, except for $\mathrm{Cr}$. The highest concentration in sediment samples was recorded for $\mathrm{Pb}$ and the lowest for Hg. Concentrations of $\mathrm{Cd}, \mathrm{Pb}, \mathrm{Hg}$ and $\mathrm{Cr}$ in the lake were recorded as 13.05, 32.65, 0.24 and $10.63 \mu \mathrm{g} \cdot \mathrm{g}^{-1}$, respectively. According to the research, there were high concentrations of heavy metals in the water, sediment, plankton and fish. Direct contamination of the water by metals or the geochemical structure of the region was cited as possible reasons for this situation [4]. The mean concentration of mercury in the sediment was much higher than TEL, and the mean concentration of cadmium was much higher than both the TEL and PEC values given by [3].

Kovada Lake is located in the Lakes Region, Turkey's most visited wetland, which is extremely rich in terms of flora and fauna. The lake gained importance due to its surrounding forest and its natural beauty, and was given national park status and protection in 1970. In an analysis of heavy metals in the sediment of the lake, which has a maximum depth of five $\mathrm{m}, \mathrm{Cr}, \mathrm{Cu}, \mathrm{Fe}, \mathrm{Mn}, \mathrm{Pb}, \mathrm{Zn}, \mathrm{Al}$ and $\mathrm{Ni}$ were present in all seasons, but $\mathrm{Cd}$ remained under the ICP-OES analytic limit in the summer and fall of 2005 [5]. Only the nickel concentration in the sediment was higher than TEL values.

Heavy metal concentrations from several fish species (Cyprinus carpio, Capoeta tinca, Leiciscus cephalus, Carassius gibelio and Silurus glanis) and sediment samples from six different lakes in Tokat province (Bedirkale, Boztepe, Belpınarı, Avara, Ataköy and Akın) were determined by [6] in the spring and summer of 
Table 1. Heavy metal concentrations $\left(\mathrm{mg} \mathrm{g}^{-1} \mathrm{DW}\right)$ in sediment samples from different lakes in Turkey.

\begin{tabular}{|c|c|c|c|c|c|c|c|c|c|}
\hline $\begin{array}{l}\text { Heavy metal } \\
\text { conc. } \\
\text { Lakes }\end{array}$ & As & Cd & $\mathrm{Cr}$ & $\mathbf{C u}$ & $\mathbf{P b}$ & Hg & $\mathbf{N i}$ & Zn & References \\
\hline Beyşehir Lake & - & $13.05^{1,2}$ & 10.63 & - & 32.65 & $0.24^{1}$ & - & - & [4] \\
\hline Kovada Lake & - & nd-0.27 & $6.63-17.59$ & $4.65-13.77$ & $1.96-4.42$ & - & $9.13-25.93^{1}$ & $12.82-33.42$ & [5] \\
\hline $\begin{array}{c}\text { (Tokat Lakes) } \\
\text { Bedirkale }\end{array}$ & - & - & $4.5-6.1$ & $5.1-8.2$ & $2.9-3.4$ & - & $51.1-53.6^{1,2}$ & $33.7-38.9$ & \multirow{6}{*}{ [6] } \\
\hline Boztepe & - & - & $6.4-7.8$ & $4.7-6.1$ & $6.7-7.0$ & - & $51.6-55.4^{1,2}$ & $23.3-23.9$ & \\
\hline Belpınarı & - & - & $9.4-10.7$ & $5.8-6.3$ & $3.9-4.0$ & - & $37.8-38.0^{1}$ & $26.5-29.7$ & \\
\hline Avara & - & - & $5.1-5.6$ & $3.4-3.7$ & $3.8-5.1$ & - & $42.1-42.7^{1}$ & $30.4-32.3$ & \\
\hline Ataköy & - & - & $4.7-4.9$ & $6.3-6.8$ & $2.7-3.1$ & - & $50.6-55.0^{1,2}$ & $24.7-25.0$ & \\
\hline Akın & - & - & $4.4-4.6$ & $4.6-5.0$ & $2.9-3.5$ & - & $40.7-43.1^{1}$ & $23.3-26.5$ & \\
\hline \multirow{2}{*}{ Hazar Lake } & - & & $29.0-35.0$ & $24.0-51.0^{1(\mathrm{H})}$ & nd & & $41.0^{1}$ & $49.0-70.0$ & [7] \\
\hline & - & nd & $87.70 \pm 43.34^{1}$ & $46.32 \pm 9.14^{1}$ & $1.14 \pm 3.49$ & & $49.50 \pm 28.61^{1,2}$ & $27.09 \pm 10.26$ & [8] \\
\hline \multirow[t]{2}{*}{ Terkos Lake } & & $0.56-1.16^{1}$ & $\begin{array}{c}91.88- \\
123.92^{1,2(\mathrm{H})}\end{array}$ & $5.94-33.09$ & $\begin{array}{c}22.61- \\
62.51^{1(\mathrm{H})}\end{array}$ & & $\begin{array}{l}25.07- \\
39.41^{1}\end{array}$ & $\begin{array}{l}76.22- \\
137.55^{1}\end{array}$ & [9] \\
\hline & - & $0.02-0.12$ & $0.83-4.88$ & $0.25-1.03$ & $0.42-2.39$ & - & $1.84-8.93$ & $0.74-8.36$ & [12] \\
\hline \multirow[t]{2}{*}{ Uluabat Lake } & - & $2.0^{1}$ & 9.0 & 12.0 & 13.0 & - & 8.0 & 1.0 & [13] \\
\hline & - & $0.69^{1}$ & $57.9^{1}$ & $119.2^{1}$ & $110.7^{1}$ & - & $209.4^{1,2}$ & $171.0^{1}$ & [14] \\
\hline Işıklı Lake & $1.14-16.33^{1}$ & $0.09-3.06^{1}$ & $\begin{array}{c}11.60- \\
269.55^{2(\mathrm{H})}\end{array}$ & $\begin{array}{c}2.68- \\
38.84^{1(\mathrm{H})}\end{array}$ & & & $\begin{array}{c}11.23- \\
211.16^{1,2(\mathrm{H})}\end{array}$ & $\begin{array}{c}16.34- \\
159.56^{1(\mathrm{H})}\end{array}$ & [15] \\
\hline Yeniçağa Lake & - & $0.8^{1}$ & $92.8^{1}$ & - & 16 & - & - & - & [16] \\
\hline Mogan Lake & - & - & 28.55 & 15.13 & 0.82 & - & - & 13.79 & [17] \\
\hline Karataş Lake & - & $0.11-0.25$ & $\begin{array}{c}13.82- \\
53.13^{1(\mathrm{H})}\end{array}$ & $1388-32.27$ & $0.54-1.13$ & - & $\begin{array}{c}47.16- \\
203.92^{1,2}\end{array}$ & $12.92-45.00$ & [18] \\
\hline SQGs & As & Cd & $\mathrm{Cr}$ & $\mathrm{Cu}$ & $\mathbf{P b}$ & $\mathrm{Hg}$ & $\mathbf{N i}$ & Zn & Reference \\
\hline TEL $^{1}$ & 5.9 & 0.596 & 37.3 & 35.7 & 35.0 & 0.174 & 18.0 & 123 & \\
\hline PEC $^{2}$ & 33.0 & 4.98 & 111.0 & 149.0 & 128.0 & 1.06 & 48.6 & 459.0 & [3] \\
\hline
\end{tabular}

${ }^{1}$ Every superscript with 1 for heavy metal concentrations mean the concentration exceeds the TEL value; ${ }^{2}$ Every superscript with 2 for heavy metal concentrations mean the concentration exceeds the PEC value.

2003-2004. In the fish samples, the maximum $\mathrm{Fe}, \mathrm{Zn}, \mathrm{Cu}, \mathrm{Pb}, \mathrm{Cr}$, $\mathrm{Mn}$ and $\mathrm{Ni}$ concentrations were 167, 48.6, 3.6, 2.8, 1.6, 64.3 and $5.6 \mu \mathrm{g} \cdot \mathrm{g}^{-1}$, respectively. As for the sediment samples, the maximum $\mathrm{Fe}, \mathrm{Mn}, \mathrm{Zn}, \mathrm{Cu}, \mathrm{Pb}, \mathrm{Cr}$ and Ni concentrations of were 2138, 232, 38.9, 8.2, 7.0, 10.7 and $55.4 \mu \mathrm{g} \cdot \mathrm{g}^{-1}$, respectively. The nickel values of three of the six lakes (Bedirkale, Boztepe ve Ataköy) exceeded both the TEL and the PEC values for nickel outlined by [3].

Lake Hazar (Elazığ, Turkey) is one of the largest and deepest lakes in Eastern Anatolia. Alburnus heckeli and Aphanius asquamatus are native fish species of the lake. [7] measured the concentration of heavy metals and natural gross radioactivity in the surface water and sediment of the lake. Samples were taken from three sites during 2004 and 2005. The results showed that, in general, concentrations of heavy metals (Zn, Fe, Mn, Ni, Cu and $\mathrm{Pb}$ ) and major elements ( $\mathrm{Na}, \mathrm{K}, \mathrm{Ca}, \mathrm{Mg}$ ) in the water did not exceed the four different guidelines (WHO; World Health Organization, 1999, EC; Europe Community, 1998, EPA; Environment Protection Agency, 2002 and TSE-266; Turkish Standard, 1997). The sediment heavy metals and major elements concentration were found to decrease in the sequence $\mathrm{Fe}>\mathrm{Mg}>\mathrm{Ca}>\mathrm{Mn}>\mathrm{Zn}>\mathrm{Ni}>\mathrm{Cr}>\mathrm{Cu}>\mathrm{Co}>\mathrm{Pb}$. Of the heavy metals in the sediment (depth: $8 \mathrm{~m}$ ), only the nickel concentrations and mean $\mathrm{Cu}$ highest value exceeded the highest TEL 
values indicated by [3].

In an additional study of the same lake conducted by [8] heavy metal concentrations (Cd, $\mathrm{Cr}, \mathrm{Cu}, \mathrm{Fe}, \mathrm{Mn}, \mathrm{Ni}$, $\mathrm{Pb}$ and $\mathrm{Zn}$ ) were reported in the water, sediment, sago pondweed (Potamogeton pectinatus L.) and the muscle, livers and gills of freshwater fish (Capoeta capoeta umbla). Samples of these items were collected seasonally between 2004 and 2005 from three separate sites. The highest concentrations of metal in the water samples were found for Fe. As for sediment, the highest concentration was recorded for $\mathrm{Mn}$ and the lowest for Pb in all seasons and at all three sites. Accordingly, the researchers concluded that measures should be taken in Hazar Lake to prevent any further heavy metal contamination. The mean concentrations of chromium and copper in the sediment were much higher than the TEL, and the mean concentration of nickel was much higher than both the TEL and PEC values determined by [3].

A study performed by [9] on Terkos Lake, which provides a portion of the drinking water to Turkey's most important metropolitan area, Istanbul. In the May 2008 study, total metal accumulation ( $\mathrm{Al}, \mathrm{Cu}, \mathrm{Mn}, \mathrm{Pb}, \mathrm{Cd}$ and $\mathrm{Fe}$ ) in the organs and eggs of Astacus leptodactylus (Eschscholtz 1823) and in the sediment ( $\mathrm{Al}, \mathrm{Cu}, \mathrm{Mn}, \mathrm{Pb}, \mathrm{Cd}$, $\mathrm{Fe}, \mathrm{Zn}, \mathrm{Cr}, \mathrm{Ni}$ )" were examined. The sediment was determined to have high enrichment factors (EF) of $\mathrm{Zn}, \mathrm{Cr}$, $\mathrm{Cd}$ and $\mathrm{Pb}$ metals, which come from anthropogenic sources (domestic and industrial input), while they have low EFs of Fe, Ni, Cu coming from natural (terrigeneous) inputs. Moreover, these lake sediments showed no Al, Fe, $\mathrm{Ni}$ and $\mathrm{Cu}$ metal enrichment due to low contamination factor (CF) values. However, the lake sediment is moderately contaminated by $\mathrm{Zn}, \mathrm{Cr}$ and $\mathrm{Pb}$, and heavily contaminated by $\mathrm{Cd}$. The metal concentrations obtained from the sediment samples were compared with the SQGs [3] which showed that cadmium, lead (highest values), nickel and zinc concentrations exceeded TEL maximum values, and chromium exceeded both TEL and PEC maximums.

Uluabat Lake, home to Turkey's largest water lily beds and declared a Ramsar protected wetland in 1998, is located south of the Marmara Sea in Bursa province and lake has an area of between 120 and $240 \mathrm{~km}^{2}$. The Lake Uluabat drainage is located in one of the most productive agricultural regions of Turkey. There are 16 urban settlements on the lake shores, and the main human activity on the lake is fishing. In addition to fisheries and agriculture, livestock breeding is also an important activity near the lake [10] [11]. In a study conducted by [12] on Uluabat Lake between November 2001 and September 2002, water and sediment samples taken at different stations and in various months were examined. The highest mean levels of $\mathrm{Cu}\left(1.19 \pm 0.05 \mu \mathrm{g} \cdot \mathrm{g}^{-1}\right), \mathrm{Cr}(4.88 \pm 0.30$ $\mu \mathrm{g} \cdot \mathrm{g}^{-1}, \mathrm{~Pb}\left(2.39 \pm 0.24 \mu \mathrm{g} \cdot \mathrm{g}^{-1}\right), \mathrm{Ni}\left(8.93 \pm 1.18 \mu \mathrm{g} \cdot \mathrm{g}^{-1}\right)$ and $\mathrm{Cd}\left(0.12 \pm 0.006 \mu \mathrm{g}^{\mathrm{g}} \mathrm{g}^{-1}\right)$ were found in May 2002 , in sediment samples. The highest concentration of $\mathrm{Zn}\left(8.36 \pm 0.13 \mu \mathrm{g} \cdot \mathrm{g}^{-1}\right)$ was recorded in September 2002 . Pb concentration levels in the sediment were consistently higher than $\mathrm{Cd}$ concentration levels. The high levels of Pb, $\mathrm{Cd}, \mathrm{Zn}$ and Fe in the sediment in the lake are a result of polluting activities around it. The heavy metal concentrations recorded by [12] did not exceed the TEL and PEC values indicated by [3].

In another study conducted in the same lake by [13], heavy metal accumulations ( $\mathrm{Cu}, \mathrm{Ni}, \mathrm{Zn}, \mathrm{Cd}, \mathrm{Pb}, \mathrm{Cr}, \mathrm{B}$, As) were measured in water, plankton and sediment samples taken from different areas of the lake between January 2003 and February 2004. The degrees of heavy metal concentrations in water and plankton samples were determined as $\mathrm{B}>\mathrm{Zn}>\mathrm{As}>\mathrm{Cd}>\mathrm{Pb}>\mathrm{Ni}>\mathrm{Cr}$ and $\mathrm{Zn}>\mathrm{Ni}>\mathrm{Cu}>\mathrm{Cr}>\mathrm{Cd}>\mathrm{Pb}$, respectively. The mobile heavy metals in the sediment samples were sequenced as $\mathrm{Pb}>\mathrm{Cu}>\mathrm{Cr}>\mathrm{Ni}>\mathrm{Cd}>\mathrm{Zn}$, whereas the degree of easily mobilizable metal concentration was determined as $\mathrm{Pb}>\mathrm{Ni}>\mathrm{Cr}>\mathrm{Cu}>\mathrm{Cd}>\mathrm{Zn}$. Only the cadmium concentration in the sediment exceeded TEL values reported by [3].

A third study done on the same lake by [14] collected two replicate sediment, zoo benthic, and water samples each month between August 2004 and July 2005 from 12 sites in Lake Uluabat. The results of the study showed relatively high occurrence of metals in the water, the sediment, and the two zoo benthic taxa. The lead, chromium, and cadmium concentration levels in the sediment samples (Table 1) were higher than those reported by [13]. One possible reason for this is that cadmium and chromium in sediments are associated with carbonate fraction, and that they are easily solubilized metals. The high levels of zinc, nickel, copper, and lead observed in the study could have been due to domestic and industrial effluents, municipal runoffs, or atmospheric deposition. Thus, the main areas in need of regular review and control are discharges, pollutants, and the long-term effects of pollutants on the lake's ecosystem. According to the results of the chemical analysis of the sediment samples, the mean concentrations of cadmium, chromium, copper, lead and zinc in the sediment were much higher than the TEL values, and in the case of nickel, higher than both the TEL and the PEC values reported by [3].

Işıklı Lake is located in the southwest of Turkey and is used for irrigation. With a depth of approximately seven m. and an area of 9.749 ha, it is fed by the Büyük Menderes, Karanlık and Kuti Rivers. There are small 
rush islands in the lake, and the surrounding shores are home to apple, cherry and peach orchards, grains fields, restaurants and hotels. The most common fish species in the lake are Cyprinus carpio, Esox lucius, Tinca tinca and two local fish species (Aphanius anatoliae and Chondrostoma meandrense). The lake is polluted by agricultural runoff and domestic effluents. Several heavy metals (Ba, As, Co, Cd, Cr, Cu, Fe, Mn, Ni and Zn) were detected in water, sediment and a total of 144 fish samples from Işıklı Lake between March 2009 and February 2010. Among the metals observed, Fe had the highest concentrations in both the water and the sediment, while Cd had the lowest value in the sediment, ranging between $0.19-3.06 \mathrm{mg} \cdot \mathrm{kg}^{-1}$. The results of this study point to a potential risk developing in the future depending on agricultural development [15]. While the concentrations of arsenic and cadmium in the sediment as well as the highest values of copper and zinc observed by the researchers were seen to be higher than the TEL values, and the highest measurement of chromium exceeded PEC values, nickel's highest observed value was greater than both the TEL and the PEC values reported by [3].

Yeniçağa Lakein Bolu province is an extremely important aquatic ecosystem due to its position on the migration route of birds coming over the straits of Istanbul and Çanakkale, the peat beds on its perimeter, and the fishing that is practiced in the lake. It is also used for irrigation and recreational purposes. In a study conducted by [16] of the water, sediment and crayfish (Astacus leptodactylus) in the lake, some heavy metal ( $\mathrm{Cr}, \mathrm{Cd}, \mathrm{Mn}$, $\mathrm{Pb}$ ) accumulation was observed, and it was determined that this situation had become dangerous both for the ecosystem and for public health. In the sampling done in 2004, the concentrations of $\mathrm{Cd}, \mathrm{Cr}, \mathrm{Mn}$, and $\mathrm{Pb}$ in the sediment were recorded as $0.8 \mu \mathrm{g} \cdot \mathrm{g}^{-1}, 92.8 \mu \mathrm{g} \cdot \mathrm{g}^{-1}, 1143 \mu \mathrm{g} \cdot \mathrm{g}^{-1}$, and $16 \mu \mathrm{g} \cdot \mathrm{g}^{-1}$, respectively. The levels of cadmium and chromium in the sediment exceeded the TEL values determined by [3].

Mogan Lake, located $20 \mathrm{~km}$ to the south of Turkey's capital city, Ankara, is near the town of Gölbaşı, which has undergone considerable development in recent years due to population increase and urban settlement. In a study of the lake conducted by [17] in March 2007, some metals ( $\mathrm{Al}, \mathrm{Cr}, \mathrm{Cu}, \mathrm{Fe}, \mathrm{Mn}, \mathrm{Pb}, \mathrm{Zn}$ and $\mathrm{V}$ ) and metalloid (Si) were observed in the water, sediment and some tissues of the fish Cyprinus carpio. The metal concentrations in the sediment samples were as follows: Cr: $22.19-41.31 \mu \mathrm{g} \cdot \mathrm{L}^{-1}$, Cu: $9.91-30.19 \mu \mathrm{g} \cdot \mathrm{L}^{-1}, \mathrm{~Pb}: 0.46-$ $1.78 \mu \mathrm{g} \cdot \mathrm{L}^{-1}$, and $\mathrm{Zn}: 11.27-18.01 \mu \mathrm{g} \cdot \mathrm{L}^{-1}$. According to the researchers, the correlation coefficient for $\mathrm{Cu}$ and Fe between the sediment and the common carp's (Cyprinus carpio) muscles was greater than that of the sediment and the fish's gills. Accordingly, measures should be taken to prevent metal contamination in future. The sediment metal concentrations obtained from the samples were compared with the SQGs [3], which showed that these concentrations did not exceed the TEL and PEC levels.

Karataş Lake, in the southwest of Burdur province, is used primarily for irrigation. It also hosts migrating birds and seven fish species, one of which is endemic. A study of the water, sediment and the gills of the Sander lucioperca in the lake done by [18] revealed some heavy metal concentrations at three sampling stations in July 2010, October 2010, January 2011 and April 2011. The heavy metal concentrations in the sediment were recorded as $\mathrm{Fe}>\mathrm{Mn}>\mathrm{Ni}>\mathrm{Zn}>\mathrm{Cr}>\mathrm{Cu}>\mathrm{Se}>\mathrm{Pb}>\mathrm{Mo}>\mathrm{Cd}$. Of the heavy metal concentrations in the sediment, chromium's highest value exceeded the TEL value, and the nickel concentration exceeded both the TEL and PEC values.

\subsection{Wetlands}

Some heavy metal concentrations of sediment samples from different wetlands and dam lakes in Turkey are presented in Table 2.

Akyatanis the biggest fishery lagoon in Iskenderun Bay on Turkey’s Mediterranean coast. Akyatan Lagoon is a multipurpose wetland ecosystem that has important contributions to the local economy, such as aquaculture and touristic activities [11]. In a study of the lagoon carried out by [19] between December 2000 and November 2001 which looked at seasonal changes in accumulations of the heavy metals $\mathrm{Pb}, \mathrm{Cu}, \mathrm{Zn}, \mathrm{Cd}$, Fe in seston, benthos, and sediment samples, it was observed that heavy metal accumulation in the sediment was ordered as $\mathrm{Fe}>$ $\mathrm{Pb}>\mathrm{Zn}>\mathrm{Cu}>\mathrm{Cd}$. The seasonal changes of metal concentrations in these samples may be attributable to natural factors like the growth and reproductive cycles of the organisms and changes in the water temperature. The sediment cadmium and lead concentrations observed in the study were greater than the TEL values for these metals indicated by [3].

Yedigöller is the nearest wetland to the Kütahya city center and provides irrigation water to some of the farmland surrounding it. Yedigöller is eutrophic, and has been used as a waste disposal area (landfill) since 1977. Of the seven lakes in the wetlands, two are now dry. [20] stress that while the Cd and Hg concentrations in the 
Table 2. Heavy metal concentrations $\left(\mathrm{mg} \cdot \mathrm{g}^{-1} \mathrm{DW}\right)$ in sediment samples from different wetlands and dam lakes in Turkey.

\begin{tabular}{|c|c|c|c|c|c|c|c|c|c|}
\hline $\begin{array}{l}\begin{array}{r}\text { Heav } \\
\text { metal cons }\end{array} \\
\text { Wetlands and } \\
\text { Dam Lakes }\end{array}$ & As & Cd & $\mathrm{Cr}$ & $\mathrm{Cu}$ & $\mathbf{P b}$ & Hg & $\mathrm{Ni}$ & Zn & References \\
\hline Akyatan Lagoon & - & $1.41-1.61^{1}$ & - & $15.87-22.81$ & $35.14-58.40^{1}$ & - & - & $27.90-52.46$ & [19] \\
\hline Yedi Göller & - & nd & $43.20-43.93^{1}$ & $67.80-68.53^{1}$ & 30.67 - 32.67 & nd & $59.87-60.33^{1,2}$ & $68.47-104.13$ & [20] \\
\hline Seyhan Dam Lake & - & $2.15 \pm 0.38^{1}$ & $118.95 \pm 21.7^{1,2}$ & $19.80 \pm 4.57$ & - & - & - & $39.09 \pm 6.50$ & [21] \\
\hline Porsuk Dam Lake & - & $3.36 \pm 0.13^{1}$ & $78.40 \pm 4.57^{1}$ & $26.08 \pm 1.20$ & $90.00 \pm 40.66^{1}$ & nd & $159.12 \pm 5.65^{1,2}$ & $656.40 \pm 32.39^{1,2}$ & \multirow{2}{*}{ [22] } \\
\hline Enne Dam Lake & - & $5.04 \pm 0.15^{1,2}$ & $59.08 \pm 1.79^{1}$ & $27.84 \pm 0.68$ & $88.96 \pm 3.22^{1}$ & nd & $136.82 \pm 5.10^{1,2}$ & $272.00 \pm 11.47^{1}$ & \\
\hline $\begin{array}{l}\text { Atatürk Dam Lake } \\
\text { Bozyazı (Bozova) }\end{array}$ & - & nd & - & 14.57 & nd & nd & $43.69^{1}$ & 60.79 & \multirow{2}{*}{ [23] } \\
\hline $\begin{array}{l}\text { Akpınar } \\
\text { (Adıyaman) }\end{array}$ & - & nd & - & 22.70 & nd & nd & $139.69^{1,2}$ & 59.14 & \\
\hline Atatürk Dam Lake & - & nd & - & $35.05 \pm 5.02$ & - & nd & $72.50 \pm 28.42^{1,2}$ & $35.15 \pm 3.32$ & {$[24]$} \\
\hline $\begin{array}{l}\text { Demirköprü } \\
\text { Dam Lake }\end{array}$ & - & $0.70-0.82^{1}$ & $3.58-6.75$ & $9.3-15.1$ & $2.66-6.50$ & & $7.41-14.30$ & - & [25] \\
\hline Avşar Dam Lake & - & $0.76^{1}$ & $13.33-14.48$ & $23.47-29.98$ & $2.44-4.04$ & - & $28.25-29.99^{1}$ & - & [26] \\
\hline Geyik Dam Lake & - & nd - 2.0 & - & $11.0-120.0^{1(\mathrm{H})}$ & $28.0-31.3$ & - & $104.0-320.0^{1,2}$ & $32.0-104.0$ & [27] \\
\hline $\begin{array}{l}\text { Çatören } \\
\text { Dam Lake }\end{array}$ & - & $12.4^{1,2}$ & - & - & - & - & - & 32.0 & [28] \\
\hline SQGs & As & Cd & $\mathrm{Cr}$ & $\mathbf{C u}$ & $\mathbf{P b}$ & Hg & $\mathbf{N i}$ & Zn & Reference \\
\hline TEL $^{1}$ & 5.9 & 0.596 & 37.3 & 35.7 & 35.0 & 0.174 & 18.0 & 123 & \multirow{2}{*}{ [3] } \\
\hline PEC $^{2}$ & 33.0 & 4.98 & 111.0 & 149.0 & 128.0 & 1.06 & 48.6 & 459.0 & \\
\hline
\end{tabular}

${ }^{1}$ Every superscript with 1 for heavy metal concentrations mean the concentration exceeds the TEL value; ${ }^{2}$ Every superscript with 2 for heavy metal concentrations mean the concentration exceeds the PEC value.

sediment are below measurable values, the wetland is under the pressure of extreme pollution due to its use as a landfill. Therefore, the authors of the study maintain that several measures should be taken in the area: first and foremost, leachates from the landfill should be prevented from contaminating the underground and surface water, aerobic and anaerobic bacteria should be used to break down organic matter, waste should be sorted at its source for recycling, a proper solid waste disposal facility should be built, and water quality parameters should be periodically measured and recorded. The sediment chromium and copper concentrations recorded in the study exceeded the TEL values reported by [3], and the nickel concentrations exceeded both the TEL and PEC values.

\subsection{Dam Lakes}

Seyhan Dam Lake, built across the Seyhan River, has been in operation since 1956. It is an important dam lake in the Mediterranean Region, and was built for the purposes of flood control, irrigation and energy production. It also serves as an important recreation area for the city of Adana. [21] took sediment samples in each season of 2004-2005 (October, February, April and July) at five sampling stations in the dam lake. The sediments were seen to have metal concentrations in decreasing order as $\mathrm{Ca}>\mathrm{Fe}>\mathrm{K}>\mathrm{Mn}>\mathrm{Na}>\mathrm{Cr}>\mathrm{Zn}>\mathrm{Cu}>\mathrm{Cd}$. The researchers reported that the probable reasons for the increased $\mathrm{Cd}$ and $\mathrm{Cr}$ concentrations seen in these sediment samples were agricultural activities and chrome mining in the area. Of the sediment metal concentrations observed in this study, the mean cadmium concentration was greater than the TEL value and the mean chromium concentration was greater than both the TEL and the PEC values [3].

Porsuk and Enne Dam Lakes, located in Kütahya, are freshwater reservoirs that are highly polluted because of nearby industrialization and urbanization. There are also many boron deposits and thermal springs in the region surrounding these dam lakes. A study conducted by [22] examined heavy metal concentrations in sediment sam- 
ples from both dam lakes and their bioaccumulation factors (BAFs) in various tissues (muscle, skin, gill, liver and intestine) of the common carp (Cyprinus carpio). The orders of sediment heavy metal concentrations were recorded as $\mathrm{Fe}>\mathrm{Mn}>\mathrm{Zn}>\mathrm{Ni}>\mathrm{Pb}>\mathrm{Cr}>\mathrm{Cu}>\mathrm{Cd}>$ Se in Enne Dam Lake and $\mathrm{Fe}>\mathrm{Zn}>\mathrm{Mn}>\mathrm{Ni}>\mathrm{Pb}>\mathrm{Cr}>$ $\mathrm{Cu}>\mathrm{Cd}>\mathrm{Se}>\mathrm{Ag}$ in Porsuk Dam Lake. There were no significant differences between sediment heavy metal concentrations in the two dam lakes. Hg concentration in the sediment of both reservoirs was lower than the detection limit. Sediment $\mathrm{Cd}$ and $\mathrm{Pb}$ concentrations were recorded respectively as 5.04 and $88.96 \mathrm{mg} \cdot \mathrm{kg}^{-1}$ in Enne Dam Lake and 3.36 and $90.00 \mathrm{mg} \cdot \mathrm{kg}^{-1}$ in Porsuk Dam Lake. The relatively high Cd sediment concentrations in both reservoirs could be a result of direct contamination of the water by $\mathrm{Cd}$ or the geochemical structure of the region. While the mean concentrations of zinc in Porsuk Dam Lake and cadmium in Enne Dam Lake greatly exceed both the TEL and PEC values, the mean concentrations of chromium, lead and nickel in both reservoirs, with the addition of cadmium in Porsuk Dam Lake, exceed only the TEL values reported by [3].

Atatürk Dam Lake, on the Euphrates River, is the largest reservoir in Turkey. It is used for irrigation and electrical energy production purposes. It has a surface area of about 81,700 ha and a volume of 48,700,000,000 $\mathrm{m}^{3}$, and 28 fish species are known to inhabit its waters. Industrial development and anthropogenic waste affect this reservoir, and the population in this region has recently increased [23] [24]. In a study conducted in 1997 by [23], heavy metal concentrations ( $\mathrm{Cd}, \mathrm{Co}, \mathrm{Cu}, \mathrm{Fe}, \mathrm{Hg}, \mathrm{Mn}, \mathrm{Mo}, \mathrm{Ni}, \mathrm{Pb}$ and $\mathrm{Zn}$ ) were examined in the water, sediment and several fish species (Acanthobrama marmid, Chalcalburnus mossulensis, Chondrostoma regium, Carasobarbus luteus, Capoetta trutta and Cyprinus carpio) from Atatürk Dam Lake. Of the heavy metals tested for, $\mathrm{Cd}, \mathrm{Co}, \mathrm{Hg}, \mathrm{Mo}$ and $\mathrm{Pb}$ were not detected in either water, sediment or fish samples, while Ni was observed to be at undetectable levels in the fish samples. $\mathrm{Cu}, \mathrm{Fe}, \mathrm{Mn}$ and $\mathrm{Ni}$ concentrations in the sediments from Akpinar station were higher than those from Bozyazi station. The researchers concluded that there was a general absence of serious heavy metal contamination in the reservoir, and the concentrations of elements that were observed were attributable to geological sources. Of the values recorded in the study, the nickel concentrations from Akpınar station exceeded both the TEL and PEC values, while those from Bozyazı station exceeded only the TEL for sediment levels reported by [3].

A later study conducted by [24] observed trace element concentrations in water, sediment and fish samples (Carassius auratus, Capoeta trutta and Cyprinus carpio) collected from Atatürk Reservoir. The accumulation orders of trace elements were as follows: $\mathrm{Fe}>\mathrm{Zn}>\mathrm{Cu}=\mathrm{Se}$ in the water, and $\mathrm{Fe}>\mathrm{Mn}>\mathrm{Ni}>\mathrm{Zn}>\mathrm{Cu}>\mathrm{Se}$ in the sediment. The accumulation order of trace elements in the tissues of the fish species was similar to one another. The researchers indicated that measures should be taken to preserve the present situation in the reservoir. The mean nickel concentration value obtained from the sediment samples were compared with SQG [3], and it was found that, similar to the study undertaken in the same area by [23], the value exceeded both TEC and PEC values.

Demirköprü Dam Lake, located in Manisa province on the Gediz River in western Anatolia, has a maximum capacity of 1,320,000,000 $\mathrm{m}^{3}$ and an area of $47.66 \mathrm{~km}^{2}$. Contamination studies must be performed on the reservoir at regular intervals as the reservoir is used for agricultural irrigation purposes and has a significant impact on both the environment and public health. In a 2005 study undertaken by [25], heavy metal concentrations in the surface water, sediment and fish (Cyprinus carpio) were measured at two different stations on the reservoir. It was observed that heavy metal $(\mathrm{Cd}, \mathrm{Cr}, \mathrm{Cu}, \mathrm{Fe}, \mathrm{Ni}, \mathrm{Pb})$ concentrations in the water generally did not exceed six different guidelines. Heavy metal concentrations in the sediments decreased in sequence as follows: $\mathrm{Fe}>$ $\mathrm{Ni}>\mathrm{Cu}>\mathrm{Cr}>\mathrm{Pb}>\mathrm{Cd}$. Only the cadmium concentrations in the sediment exceeded the TEL concentration values indicated by [3].

Avsar Dam Lake, constructed in western Turkey to help ease water problems in the Gediz Basin, is actively fished by local inhabitants. The ecosystem's quality has been compromised as a result of agricultural and human activities. In a study conducted by [26], concentrations of certain heavy metals ( $\mathrm{Cd}, \mathrm{Cr}, \mathrm{Cu}, \mathrm{Fe}, \mathrm{Ni}$ and $\mathrm{Pb}$ ) were seasonally observed in the water, the sediment and some tissues of Cyprinus carpio from the dam lake. The heavy metal concentrations in the sediment samples were as follows: Cd: $0.34-1.23 \mathrm{mg} \cdot \mathrm{L}^{-1}$, Cr: $9.41-19.9$ $\mathrm{mg} \cdot \mathrm{L}^{-1}$, Cu: 18.2 - $38.4 \mathrm{mg} \cdot \mathrm{L}^{-1}$, Fe: 19,680 - 28,560 $\mathrm{mg} \cdot \mathrm{L}^{-1}$, Ni: $19.8-39.4 \mathrm{mg} \cdot \mathrm{L}^{-1}$ and $\mathrm{Pb}: 0.64-6.35 \mathrm{mg} \cdot \mathrm{L}^{-1}$. Heavy metal concentrations in the lake sediments decreased in the order: $\mathrm{Fe}>\mathrm{Ni}>\mathrm{Cu}>\mathrm{Cr}>\mathrm{Pb}>\mathrm{Cd}$. The researchers maintained that the reservoir may be at risk in the future, depending on regional agricultural development. The researchers recommended that contamination studies be performed at regular intervals, as the reservoir is used for agricultural irrigation purposes and its condition affects both the environment and public health. The sediment metal concentrations were compared with the SQG [3], and it was found that both the cadmium 
and nickel concentrations exceeded TEL values.

Geyik Dam Lake, which was constructed on the Sarıçay River in 1988 to provide irrigation and industrial water, supplies $38 \mathrm{hm}^{3}$ of domestic water to the town of Milas. In a study conducted on the reservoir, new information was obtained on the accumulation of heavy metals (Cd, $\mathrm{Co}, \mathrm{Cu}, \mathrm{Fe}, \mathrm{Mn}, \mathrm{Ni}, \mathrm{Pb}$, and $\mathrm{Zn}$ ) in fish tissue (Cyprinus carpio and Carassius carassius), sediment, and water from the reservoir. Sediment samples from the study showed high Fe concentrations in winter and summer, but low concentrations of $\mathrm{Cd}$ and $\mathrm{Pb}$ in summer, and likewise, low $\mathrm{Co}$ and $\mathrm{Cu}$ in winter [27]. The mean concentration of nickel in the sediment was much higher than both TEL and PEC values, and the highest value for copper concentration exceeds the TEL value reported by [3].

Çatören Dam Lake is in Seydisuyu Basin in the Kırka district of Eskişehir province. This is one of Turkey's most important boron mining regions. In the reservoir some limnological parameters as well as macro-micro accumulations of certain elements in the water, the sediment, and some tissues of Cyprinus carpio, Cyprinus carpio var. specularis and Tinca tinca, which are important fish for regional trade [28]. The study noted that total P, Zn, Mn, As and B sediment concentrations detected at the output of the reservoir were significantly higher than those detected at the input. The highest As and $\mathrm{Zn}$ values were recorded at $12.4 \mathrm{mg} \cdot \mathrm{kg}^{-1}$ and $32 \mathrm{mg} \cdot \mathrm{kg}^{-1}$, respectively. The cadmium concentration in the sediment exceeded both the TEL and PEC values set by [3].

\subsection{Rivers and Streams}

Some heavy metal concentrations in different rivers and sediment samples (Turkey) are presented in Table 3 .

The Gediz and Buyuk Menderes (BM) Rivers, which have great economic importance for Turkey, in order to determine the extent of environmental contamination [29]. The study reported significant contamination levels in both rivers, with high levels of $\mathrm{Pb}, \mathrm{Cr}, \mathrm{Mn}$ and $\mathrm{Zn}$ being reported in the Gediz River and of $\mathrm{Co}, \mathrm{Mn}$, and $\mathrm{Zn}$ in the BM River. This contamination was likely caused by industrial waste, according to speciation studies. While the chromium and nickel concentrations in both rivers exceeded both TEL and PEC values, the copper and lead concentrations in both the rivers exceeded only the TEL and the mean zinc value in the Gediz River exceeded only the TEL value as reported by [3].

In a separate study undertaken on the Sakarya River, [30] collected water and sediment samples from three different stations along the river between May and September 2003. The results showed differences between different seasons, sampling stations, and nature of the samples (sediment or water). The mean levels of heavy metals in the sediment samples (copper, nickel, chromium, lead, cadmium, zinc) are as follows: $4.630 \mu \mathrm{g} \cdot \mathrm{g}^{-1}$, $13.520 \mu \mathrm{g} \cdot \mathrm{g}^{-1}, 8.780 \mu \mathrm{g} \cdot \mathrm{g}^{-1}, 2.640 \mu \mathrm{g} \cdot \mathrm{g}^{-1}$, nd, $9.990 \mu \mathrm{g} \cdot \mathrm{g}^{-1}$, and in the water samples as: $0.85 \mu \mathrm{g} \cdot \mathrm{g}^{-1}, 1.050$ $\mu \mathrm{g} \cdot \mathrm{g}^{-1}, 0.027 \mu \mathrm{g} \cdot \mathrm{g}^{-1}, 1.786 \mu \mathrm{g} \cdot \mathrm{g}^{-1}, 0.236 \mu \mathrm{g} \cdot \mathrm{g}^{-1}$ and $0.173 \mu \mathrm{g} \cdot \mathrm{g}^{-1}$, respectively. The researchers concluded that, while several studies have shown that the Sakarya River has a high level of contamination, when the total heavy metal concentrations in sediments are taken into account, the lower part of the river is seen to have a higher level of contamination than the upper part. Of the heavy metal concentrations in the sediment, the mean concentration of nickel is much higher than the TEL reported by [3].

The Yesilirmak River has a total basin area of $2352.8 \mathrm{~km}^{2}$, and the river is $519 \mathrm{~km}$ long. A large part of the river flows through the city of Tokat. Concentrations of trace metals in sediment samples from the river were as follows: Cu $37.9 \mathrm{mg} \cdot \mathrm{kg}^{-1}$, Mn $392.2 \mathrm{mg} \cdot \mathrm{kg}^{-1}$, Zn $126.2 \mathrm{mg} \cdot \mathrm{kg}^{-1}$, Fe $3726 \mathrm{mg} \cdot \mathrm{kg}^{-1}$, and $\mathrm{Pb} 29.6 \mathrm{mg} \cdot \mathrm{kg}^{-1}$ [31]. While among the total concentrations of trace metals analyzed in the study, copper and zinc were shown to exceed the TEL values given by [3], in another study of the same area, [32] found that maximum metal concentrations for copper (38.7 $\mu \mathrm{g} \cdot \mathrm{g}^{-1}$ ) exceeded [3]'s reported TEL value for copper, and mean nickel values (79.2 $\mu \mathrm{g} \cdot \mathrm{g}^{-1}$ ) exceeded both the TEL and PEC values for nickel.

The Tigris River has its start in the mountains of Eastern Anatolia and flows southeastwards from Turkey into Iraq. Samples taken by [33] from study sites on the river and a reference site on Resan Creek between June 2000 and May 2001 returned metal levels of the sediments sequenced as: $\mathrm{Fe}>\mathrm{Mn}>\mathrm{Cu}>\mathrm{Co}>\mathrm{Zn}$. The highest copper and nickel concentrations in the sediment equaled [3]'s recommended TEL highest values, and exceeded the PEC values.

The Dipsiz Stream is $88 \mathrm{~km}$ long and yields about $1000 \mathrm{~L} / \mathrm{s}^{-1}$. It flows into the Buyuk Menderes River in southwestern Turkey. In three surveys carried out on the stream in April, July and October 2004 [34], heavy metal concentrations ( $\mathrm{Cd}, \mathrm{Cr}, \mathrm{Cu}, \mathrm{Pb}$ and $\mathrm{Zn}$ ) were measured in the water, sediment and muscle and gill tissues of Leuciscus cephalus in Yatagan Basin, the site of a geothermal power plant. The mean sediment concentrations of cadmium and lead were shown to be much higher than the TEL reported by [3]. 
Table 3. Heavy metal concentrations $\left(\mathrm{mg} \mathrm{g}^{-1} \mathrm{DW}\right)$ in sediment samples from different rivers and streams in Turkey.

\begin{tabular}{|c|c|c|c|c|c|c|c|c|c|}
\hline $\begin{array}{l}\begin{array}{r}\text { Heavy metal } \\
\text { cons. }\end{array} \\
\begin{array}{l}\text { Rivers and } \\
\text { Streams }\end{array}\end{array}$ & As & Cd & $\mathrm{Cr}$ & $\mathbf{C u}$ & $\mathbf{P b}$ & Hg & $\mathbf{N i}$ & Zn & References \\
\hline $\begin{array}{c}\text { Büyük } \\
\text { Menderes River }\end{array}$ & - & - & $\begin{array}{c}165.0 \pm \\
7.0^{1,2}\end{array}$ & $\begin{array}{c}137.0 \pm \\
5.0^{1}\end{array}$ & $\begin{array}{c}54.0 \pm \\
8.0^{1}\end{array}$ & - & $\begin{array}{c}315.0 \pm \\
25.0^{1,2}\end{array}$ & $\begin{array}{c}120.0 \pm \\
10.0\end{array}$ & \multirow{2}{*}{ [29] } \\
\hline Gediz River & - & - & $\begin{array}{c}200.0 \pm \\
6.0^{1,2}\end{array}$ & $\begin{array}{c}140.0 \pm \\
3.0^{1}\end{array}$ & $\begin{array}{c}128.0 \pm \\
15.0^{1}\end{array}$ & - & $\begin{array}{c}106.0 \pm \\
10.0^{1,2}\end{array}$ & $\begin{array}{c}160.0 \pm \\
15.0^{1}\end{array}$ & \\
\hline Kızılırmak River & - & $\begin{array}{l}0.92 \pm \\
0.03^{1}\end{array}$ & - & $\begin{array}{l}9.95 \pm \\
2.65\end{array}$ & $\begin{array}{c}0.62 \pm \\
0.04\end{array}$ & - & $\begin{array}{c}47.91 \pm \\
6.43^{1}\end{array}$ & $\begin{array}{c}34.62 \pm \\
6.46\end{array}$ & [35] \\
\hline $\begin{array}{l}\text { Sakarya River } \\
\text { (in the lower part) }\end{array}$ & - & nd & $\begin{array}{c}9.47 \pm \\
2.7\end{array}$ & $\begin{array}{c}5.63 \pm \\
1.70\end{array}$ & $\begin{array}{c}4.31 \pm \\
0.40\end{array}$ & - & $\begin{array}{c}18.17 \pm \\
2.10^{1}\end{array}$ & $\begin{array}{c}10.55 \pm \\
2.20\end{array}$ & [30] \\
\hline TigrisRiver & - & nd & - & $\begin{array}{c}25.39- \\
194.53^{1,2(\mathrm{H})}\end{array}$ & nd & - & $\begin{array}{c}36.68- \\
170.83^{1,2(\mathrm{H})}\end{array}$ & $\begin{array}{l}17.09- \\
66.26\end{array}$ & [33] \\
\hline \multirow{2}{*}{ Yeşilırmak River } & & 0.55 & & $38.7^{1}$ & 17.3 & & \multirow[t]{2}{*}{$79.2^{1,2}$} & 45.5 & [32] \\
\hline & & & & $37.9^{1}$ & 29.6 & & & $126.2^{1}$ & [31] \\
\hline Dipsiz Stream & - & $\begin{array}{c}0.80 \pm \\
0.60^{1}\end{array}$ & $\begin{array}{c}19.70 \pm \\
15.60\end{array}$ & $\begin{array}{c}13.00 \pm \\
9.00\end{array}$ & $\begin{array}{l}83.60 \pm \\
56.20^{1}\end{array}$ & - & - & $\begin{array}{l}37.00 \pm \\
26.00\end{array}$ & [34] \\
\hline $\begin{array}{c}\text { Delice Stream } \\
\text { (K1z1lırmak Basin) }\end{array}$ & - & - & $\begin{array}{c}74.4- \\
237.4^{1,2}\end{array}$ & $\begin{array}{c}7.11- \\
57.3^{1(\mathrm{H})}\end{array}$ & $\begin{array}{l}27.99- \\
39.7^{1(\mathrm{H})}\end{array}$ & $\begin{array}{c}4.16- \\
14.81^{1,2}\end{array}$ & - & $\begin{array}{c}86.2- \\
170.6^{1(\mathrm{H})}\end{array}$ & [36] \\
\hline \multicolumn{10}{|l|}{ Felent Stream } \\
\hline Upstream & $\begin{array}{c}15.56- \\
119.90^{1,2(\mathrm{H})}\end{array}$ & - & $\begin{array}{l}48.38- \\
62.69^{1}\end{array}$ & $\begin{array}{l}9.62- \\
19.53\end{array}$ & $\begin{array}{c}11.73- \\
230.75^{1,2(\mathrm{H})}\end{array}$ & - & - & $\begin{array}{c}39.31- \\
343.25^{1(\mathrm{H})}\end{array}$ & \multirow{3}{*}{ [28] } \\
\hline Lentic & $27.12^{1}$ & - & $53.47^{1}$ & 22.29 & 11.29 & - & - & 54.69 & \\
\hline Downstream & $\begin{array}{l}14.84- \\
18.53^{1}\end{array}$ & - & $\begin{array}{r}33.42- \\
46.29^{1(\mathrm{H})}\end{array}$ & $\begin{array}{c}15.47- \\
163.48^{1,2(\mathrm{H})}\end{array}$ & 8.52.123.66 $6^{1(\mathrm{H})}$ & - & - & $\begin{array}{c}56.13- \\
138.00^{1(\mathrm{H})}\end{array}$ & \\
\hline SQGs & As & Cd & $\mathrm{Cr}$ & $\mathbf{C u}$ & $\mathbf{P b}$ & Hg & $\mathbf{N i}$ & Zn & Reference \\
\hline TEL $^{1}$ & 5.9 & 0.596 & 37.3 & 35.7 & 35.0 & 0.174 & 18.0 & 123 & \multirow{2}{*}{ [3] } \\
\hline PEC $^{2}$ & 33.0 & 4.98 & 111.0 & 149.0 & 128.0 & 1.06 & 48.6 & 459.0 & \\
\hline
\end{tabular}

${ }^{1}$ Every superscript with 1 for heavy metal concentrations mean the concentration exceeds the TEL value; ${ }^{2}$ Every superscript with 2 for heavy metal concentrations mean the concentration exceeds the PEC value.

The Kizılırmak River the longest river within the borders of Turkey (1355 km) is currently used as a source of drinking water for Ankara, the capital of Turkey. The study carried out in Kizılırmak River (in April and October 2005) has been conducted to determine cadmium, cobalt, copper, chromium, iron, manganese, nickel, lead and zinc concentrations in the five different tissues of carp (gills, muscle, liver, kidney and gonads), and in the surface water, sediment samples, and aquatic plant from the study area. The highest sediment heavy metal concentration was recorded for $\mathrm{Fe}$, and the lowest for $\mathrm{Cd}$ and $\mathrm{Pb}$. The origin of the elements could be attributed to the geological environment surrounding the river, and some industrial facilities near the river. Results of correlation coefficient analysis gained from the study suggested that metal concentrations in the sediment and aquatic plant are the most curucial factors governing the metal body concentration of fish [35]. The cadmium and nickel concentrations in the sediment exceeded the TEL value for these metals outlined by [3]. The accumulation of heavy metals such as $\mathrm{Pb}, \mathrm{Hg}, \mathrm{Co}, \mathrm{Cr}, \mathrm{Cu}, \mathrm{Zn}$, and $\mathrm{Br}$ in Delice Stream, which is a tributary of the Kizılırmak River, were studied in water and sediment samples as well as samples of muscle and gill of three fish species (Leuciscus cephalus, Capoeta tinca, Capoeta capoeta). The samples were taken from four different stations in February, May and August 2008. The metal concentrations in the sediment samples were sequenced as: $\mathrm{Cr}>\mathrm{Zn}>\mathrm{Pb}>\mathrm{Cu}>\mathrm{Co}>\mathrm{Hg}>\mathrm{Br}$ [36]. According to the researchers, if these water bodies are to be used as drinking water and agricultural water sources, they must be biomonitored in order to keep tabs on their heavy 
metal concentrations. The chromium and mercury concentrations in the sediment exceeded both the TEL and the PEC values for these metals outlined by [3]. The lead, copper and zinc concentrations (high values) exceeded only the TEL.

Felent Stream is one of the most important branches of Porsuk Stream in the Sakarya River Basin. It is used for irrigation, industrial water supply, domestic waste disposal and fishing [28]. Seasonal sediment samples were taken from Felent Stream in 2011 at three different locations: the mining-agricultural section (upstream), the lenthic section (a reservoir) and the urban section (downstream). The metal concentrations in these sediment samples were then compared with SQG [3]. The comparison showed that the upstream and downstream section's heavy metal concentration values were similar to those indicated by [3]. As for the lenthic section, the arsenic and chromium concentrations were seen to be higher than the TEL values given by [3].

According to water quality regulations [37], Turkey’s inland waters are divided into four classes. While some of the lakes mentioned in this review, such as Beyşehir, Uluabat and Yeniçağa Lakes, have heavy metal concentrations higher than permissible for drinking water, others such as Kovada and Işıklı Lakes don't have this problem. Additionally, the sediment heavy metal levels in Uluabat and Yeniçağa Lakes were found to be extremely high, and in this type of lake, create a risk for food contamination, as in the case of the crayfish (Astacus leptodactylus) that are caught in Yeniçağa Lake.

Although the geochemical structure of the region does play a role in the increase of heavy metal levels in lake sediment, the main cause has been shown to be terrestrial inputs originating from anthropogenic (domestic and industrial) sources which are delivered via rivers and rainfall. Especially harmful are effluents from urban settlements on the lake's shores and agricultural development in the drainage basin. Studies done in different years on the same aquatic systems have shown that heavy metal concentrations in the water and sediment have been on the increase. This result points to the fact that contamination is continuing and the measures that have been taken are not effective enough. When the heavy metal concentrations in the lake sediment mentioned in this review are examined in light of the TEL and PEC levels for sediment reported by [3], it can be seen that in many cases, the nickel concentrations exceeded the TEL values, followed by cadmium. It is common knowledge that ore, smelter and refinery waste are the major causes of nickel contamination. Nickel, which is widely used in the electronics, steel, battery and food production industries and can be found in dissolvable form in aquatic environments, bonds to clay minerals or organic particles (especially those such as humic and fulvic acid). Cadmium is used in the paint and battery industries, in the coating-galvanizing and aircraft industries, due to its non-corrosive properties, in insecticide formulation, and as a stabilizer in plastics production. Because it is the element with the highest potential to dissolve in water, its diffusion rate in natural environments is extremely high [1]. The results of this review indicate that heavy metal contamination in lake systems in Turkey should be taken into account when developing management strategies for protecting aquatic environments.

The contamination sources that lead to high heavy metal concentrations in wetland and reservoir sediment are no different from those that affect other aquatic systems. For many reservoirs, for example Demirköprü, Avşar, Seyhan and Geyik reservoirs, it has been suggested that the heavy metal levels in the sediment result from agricultural and domestic waste discharges. For others, primarily Atatürk Reservoir, geological sources are thought to play a role as the main contaminating element. For example, for Seyhan Reservoir, chrome mining, and for Çatören Reservoir, boron processing were found to contribute to the increase of some sediment heavy metal concentrations. In highly polluted reservoirs like Porsuk and Enne Reservoirs, on the other hand, industrialization and urbanization activities are the primary culprit. Among the reservoirs discussed (Demirköprü and Avşar Reservoirs) concentrations of especially $\mathrm{Cd}, \mathrm{Cr}, \mathrm{Ni}$ and $\mathrm{Pb}$ in the fish that are caught for food exceed tolerable values delineated by international institutions. When the heavy metal concentrations in the sediment of the wetlands and reservoirs investigated in this review are examined according to the threshold effect level (TEL) and probable effect concentrations (PEC) for sediment levels reported by [3], it is clear that in the majority of cases (Yedigöller, Porsuk and Enne Reservoirs, Avşar Reservoir, Atatürk Reservoir and Geyik Reservoir), just as in the lake ecosystems examined, of the heavy metals, nickel concentrations exceeded the TEL value, followed by cadmium. In this context, for reservoir management purposes it is necessary to determine the condition of the reservoirs and initiate monitoring programs.

When examining heavy metal levels in the sediment of rivers and streams, it has been noted that limited studies have been done on this topic. Of the areas that are included in such studies, it has been reported that especially for the Büyük Menderes, Gediz and Yeşilırmak river basins, industrial plants, agricultural lands and sites are responsible for heavy metal contamination. When the sediment heavy metal concentrations for the rivers and 
streams discussed in this study were evaluated in light of the TEL and PEC for sediment levels indicated by [3], it was determined that nickel, as well as other heavy metal concentrations like chromium, copper, mercury and lead, exceeded TEL values. In rivers like the Büyük Menderes and Gediz, which are among those with basins especially at risk for heavy contamination, chromium and nickel concentrations exceeded both TEL and PEC values. Thus, in the context of different analyses of heavy metals in the sediment of rivers, it is seen that the most effective measures to improve the quality of the river basin are to control of the quantity and concentration of input contaminants and reduce the stream's pollution load.

In conclusion, there has been considerable attention given to sediment heavy metal contamination in Turkey's freshwater ecosystems over the past 15 years. Terrestrially derived wastewater discharge, agricultural and industrial run-off and regional geological characteristics are known to be the most common sources of heavy metals in the sediments of these freshwater ecosystems. All five types of freshwater aquatic systems in Turkey are contaminated with heavy metals according to the TEL and PEC values. Moreover, the tissues of aquatic biota in the study areas have been reported as having high levels of heavy metals in them. For this reason, site-specific information should be collected to supplement the use of SQGs for evaluating sediment quality on a regional and national basis.

\section{Research Regarding Nutrient Release from Sediment in Inland Aquatic Ecosystems}

In aquatic environments, phosphorus transfer occurs between water and sediment as a result of several physical, chemical and biological events. Transfer of phosphorus from the sediment to the water is known as internal phosphorus loading. Sediment is very important for the nutrient dynamics of shallow lakes. Even in lakes where the external loading has been reduced, internal phosphorus loading from the sediment has in some cases been seen to prevent improvements in lake water quality [38] [39].

Phosphorus release amounts are estimated by comparing total filterable orthophosphate concentrations to the sediment porewater as well as overlying waters, with the water content of the sediment and the diffusion coefficient depending on the temperature. Physical, chemical and biological measures must be taken in aquatic systems in order to control eutrophication by reducing internal phosphorus load. Phosphorus release from the sediment to the lake water through molecular diffusion can generally be estimated using Fick's First Law. Accordingly, the formula specified by [40] is widely used for this purpose. Phosphorus release is dependent on a number of factors. Considered particularly important are redox sensitive mobilization from the anoxic zone a few millimeters or centimeters below the sediment surface and microbial processes. However, the mechanisms contributing to phosphorus release are sometimes specific to an individual lake [38] [39] [41].

The number of studies conducted in the last 15 years regarding the release of nutrients from the sediment to the water of some lakes and ponds in Turkey is extremely low. The first study of this type was done at Kirkgiz Pond (West Pond), one of the five Sakaryabaşı Karst Springs. These Karst Springs in Central Anatolia are part of a confined/semi-confined karst aquifer, which also has a thermal component. Kirkgiz Pond was naturally converted to a pond due to the presence of macrophytes in the spring. The pond supplies water to the Rainbow Trout Culture and Research Station, which produces approximately 40 tons of fish per year. The above-mentioned study on Kirkgiz Pond was conducted by [42] in 2000 and 2001 in order to establish changes in concentrations of phosphorus and iron in the pondwater and porewater in the littoral zone of the pond. Soluble reactive phosphorus concentrations were four to five times higher in the porewater than the pondwater, making diffusion of SRP from porewater to pondwater a distinct possibility. According to the results of the study, it seems that it would be easier to control phosphorus concentration in spring and autumn than in the warm summer months. The aim of a different study conducted at West Pond, which also supplies water to the Sakaryabaşı Fish Culture and Research Station, was to quantitatively estimate the phosphorus release from the sediment due to diffusion. The highest release rate was recorded in October 2000 as $22 \mu \mathrm{g} \cdot \mathrm{m}^{-2} \cdot \mathrm{d}^{-1}$, and the lowest was $3 \mu \mathrm{g} \cdot \mathrm{m}^{-2} \cdot \mathrm{d}^{-1}$ in January 2001. Thus, it was quantitatively shown that the sediment doesn't have a significant effect on the nutrient levels of West Pond. It was concluded that the pond's high calcium content and the sediment's limy composition were the important elements causing phosphorus release from the sediment to remain at low levels, depending on the water temperature and the $\mathrm{pH}$ values [43]. A third study, also undertaken on West Pond, had multiple aims: to determine phosphorus release from the sediment to the water using vertical sections $(5.0 \mathrm{~cm}$ sampling intervals across $20 \mathrm{~cm}$ sediment depth), to observe seasonal changes (positive-upwards and/or nega- 
tive-downwards) in the phosphorus fractional composition of the eutrophicated West Pond sediment with phosphorus cycling between the sediment and the water, and to determine which fraction or fractions potentially have the greatest effect on phosphorus release and the pond's eutrophication process. The mean release values of phosphorus from the sediment in West Pond, measured at similar depths and in months representing the seasons (April, July, October, January), varied between 9.19 (January, $0-5 \mathrm{~cm}$ ) and $119.08 \mu \mathrm{g} \cdot \mathrm{m}^{-2} \cdot \mathrm{d}^{-1}$ (October, $0-5$ $\mathrm{cm})$. The mean negative phosphorus release values according to months and depths were estimated as 1.25 $\mu \mathrm{g} \cdot \mathrm{m}^{-2} \cdot \mathrm{d}^{-1}$ (July, $5-10 \mathrm{~cm}$ ) and $46.45 \mu \mathrm{g} \cdot \mathrm{m}^{-2} \cdot \mathrm{d}^{-1}$ (October, $10-15 \mathrm{~cm}$ ). Phosphorus fractions were observed to be distributed in the pond sediment as follows: total organically bound phosphorus fraction $(\mathrm{Org} \approx \mathrm{P})>$ calcium bound phosphorus fraction $(\mathrm{Ca} \approx \mathrm{P})>$ carbonate bound phosphorus fraction $(\mathrm{CO} \approx \mathrm{P})>$ iron + aluminum bound phosphorus fraction $(\mathrm{Fe}+\mathrm{Al} \approx \mathrm{P}$ ). Similar to previous research results, the negative phosphorus release dependent on months and depths has quantitatively shown a very low flux [44]. Another study of West Pond on the topic of nitrogen release from the sediment to the water, estimated inorganic nitrogen (ammonium-nitrate) flux in months representing the seasons (April, July, October, January. Negative ammonium and nitrate flux (retention) values were observed to change between 809.48 and $2069.52 \mu \mathrm{g} \cdot \mathrm{m}^{-2} \cdot \mathrm{day}^{-1}$, at 2053.77 to 7718.10 $\mu \mathrm{g} \cdot \mathrm{m}^{-2} \cdot$ day $^{-1}$, respectively. The minimum inorganic nitrogen (ammonium-nitrate) flux value was estimated in July, and the maximum in January. The study quantitatively suggests that West Pond's sediment doesn't function as a source of nitrogen, but rather, a trap. This conclusion points to the importance of the management of macrophytes, which are found in large concentrations in the littoral zone and function as a mechanism for nitrogen removal, in pond rehabilitation efforts [45]. It can be concluded from examining the scientific data on the sediment of West Pond that the sediment is a sink, not a source, of phosphorus and inorganic nitrogen. Thus, the best management technique for the pond is conservation of the aquatic macrophytes' function in preventing and/or suppressing the dissolved inorganic phosphorus and nitrogen release from the sediment to the overlying water.

Mogan Lake, an important recreational area for metropolitan Ankara, is designated with environmental protection status as "Gölbaşı Specially Protected Area." The chief source of phosphorus in the region is waste-water, which contains detergents and fertilizers used in the nearby agricultural areas. A study was undertaken between July 2004 and June 2005 to examine the seasonal and spatial patterns of Mogan Lake's littoral sediment phosphorus and the potential for its release into the water. Sediment phosphorus release fluctuated between 0.002 and $0.062 \mu \mathrm{g} \cdot \mathrm{m}^{-2} \cdot \mathrm{d}^{-1}$ within the research period, and reached minimum and maximum values in November and June, respectively. By examining the estimated values of phosphorus release into the lake, the study has quantitatively shown that the sediment had only a minimal effect of on the trophic level of the lake. Organically-bound phosphorus fractions were estimated to make up the largest proportion of fractions preventing phosphorus release into the lake (Org $\approx \mathrm{P}: 36 \%$ ), followed by calcium-bound ( $\mathrm{Ca} \approx \mathrm{P}: 35 \%)$, iron + aluminium-bound $(\mathrm{Fe}+\mathrm{Al}$ $\approx \mathrm{P}: 16 \%)$ and carbonate-bound $\left(\mathrm{CO}_{3} \approx \mathrm{P}: 13 \%\right)$ phosphorus fractions. Internal phosphorus load was estimated to be very low, and thus, it is suggested that sediment dredging of the lake would not affect its trophic level, and would only deepen the lake [46]. A concurrent study conducted in Mogan Lake between September 2005 and August 2006 [47] examined vertical distributions of total phosphorus (TP), phosphorus fractions, iron and organic matter in the littoral sediment in a macrophyte-dominated, clear water state. Benthic macroinvertebrates and total bacteria in the sediment also were determined in the study. It was concluded that no clear seasonal or depth-related $(0-20 \mathrm{~cm})$ patterns could be seen in sediment concentrations for the measured parameters. Phosphorus release was quantitatively quite low, with negative phosphorus release $\left(-0.132 \mu \mathrm{g} \cdot \mathrm{m}^{-2} \cdot \mathrm{day}^{-1}\right) \mathrm{recorded}$ during the summer months. Sediment TP concentrations ranged between 675.00 and $1463.80 \mu \mathrm{g} \cdot \mathrm{g}^{-1} \mathrm{dry}$ weight (DW), and the trophic level of the lake was determined as eutrophic. Here, inorganic phosphorus fractions made up the largest fraction (63\%), with organic-bound phosphorus (Org $\approx \mathrm{P}$ ) constituting 37\% of total phosphorus. The low occurrence of benthic macroinvertebrates (510 - 850 individuals $/ \mathrm{m}^{-2}$ ), which are dependent on sediments with high iron content and low levels of organic matter (5.42\% - 13.30\%), affected sediment phosphorus retention. Bacterial presence in the surface sediment appeared to be positively correlated with temperature; however, anoxic conditions weren't present in the overlying water, pointing to the possibility that the bacteria retained phosphorus in their cell structures. A third study undertaken in macrophyte-dominated, clearwater state eutrophic Mogan Lake, which has extremely low positive and negative diffusional phosphorus release, examined variations in total dissolved phosphorus (TDP), soluble reactive phosphorus (SRP) and total iron (TFe) concentrations and $\mathrm{pH}$ values in the littoral sediment porewater between $0-20 \mathrm{~cm}$ depth at 5 cm intervals over a period of eleven months. The objective of this study was to document whether these values differ according to 
season and depth. The findings are discussed in terms of the dissolved oxygen, $\mathrm{pH}$ and redox potential of the overlying water and low-release data. The continued aerobic-environment low phosphorus release from Lake Mogan's sediment is due in part to low SRP concentration gradients between the overlying water and the porewater. Keeping this in mind, it should be noted that changes to the in-lake phosphorus cycling mechanisms could potentially be implemented through monitoring SRP variations in the porewater and the overlying water, and lake sediments would thus become net sources of SRP rather than net sinks. This concept is a potentially important one for lake sediment management strategies [48].

From these three studies involving sediment phosphorus release in Mogan Lake, it can be concluded that the sediments of this lake must be monitored over time, taking management measures and continued external phosphorus loading into account, to improve its management and promote the continuation of a clear water state. Consequently, two steps should be taken in order to control the eutrophication process in Lake Mogan: first, the sediment should be examined to determine its adsorption capacity, and second, a program should be implemented which monitors the lake's trophic level by recording variations in the lake water's total filterable orthophosphate concentrations.

Küçük Çekmece Lagoon, located in the Marmara Region $15 \mathrm{~km}$ to the west of Turkey’s largest metropolis, Istanbul, is a shallow sea-level wetland water source used for various purposes. It has gained widespread international importance due to its biological diversity. In a study comparing sediment nutrient release in the lagoon under field and laboratory conditions, sediment samples were taken monthly between October 2006 and February 2008. The highest readings for nitrate $\left(\mathrm{NO}_{3}-\mathrm{N}\right)$ and orthophosphate $\left(\mathrm{o}-\mathrm{PO}_{4}\right)$ obtained under field conditions were $3.39 \mathrm{mg} / \mathrm{L}^{-1}$ and $6.62 \mathrm{mg} / \mathrm{L}^{-1}$, respectively. However, under laboratory conditions, the highest value of $\mathrm{NO}_{3}-\mathrm{N}$ was measured as $3.41 \mathrm{mg} / \mathrm{L}^{-1}$, while the highest value of o- $\mathrm{PO}_{4}$ was $2.95 \mathrm{mg} \cdot \mathrm{L}^{-1}$. Using these results, the highest values for nitrate and orthophosphate flux were calculated as 3035 and $1487 \mathrm{mg} \cdot \mathrm{m}^{-2} \cdot$ day $^{-1}$, respectively. Under field conditions, significant variation was seen in the measured nutrient values between the deepest and costal stations. Under laboratory conditions, however, the measured values did not generally show such a difference. The data from the study point toward a nutrient load in the lagoon characteristic of highly eutrophic lakes. According to the study, sediment fluxes account for $45 \%$ of the nitrogen load and $85 \%$ of the phosphorus load entering the Küçük Çekmece Lagoon annually. This result shows that sediment flux plays an important role in the lagoon's eutrophication process [49]. It is a scientific fact that the pollution load of Küçük Çekmece Lagoon is continually increasing as a result of the discharge of untreated industrial and domestic waste water directly into the lagoon or the streams that feed it. With this study of the lagoon, it has been suggested that pollutants accumulate not only in the water, but also in the sediment structure, having a negative effect on the sustainability of the lagoon.

Sediment has been shown to have a significant effect on nutrient transfer in lakes, especially shallow ones. When phosphorus enters the sediment of a lake, it is employed in the chemical and biological processes of the sediment. Later, it either becomes permanently deposited in the sediment or is released by various processes and returns to the water column in dissolved form through the porewater. It should be emphazised, however, that sediment can differ drastically from one lake to another, and even within the same lake, may have highly variable chemical composition. Factors such as dry weight, organic content, and the presence of iron, aluminum, manganese, calcium, clay and other elements with the capacity to bind and release phosphorus may affect interactions between the water and the sediment. It can be understood from this review that there have been an extremely limited number of studies on this topic conducted in Turkey. Due to their significant effect on lake water concentrations, awareness of sediment-water interaction and the processes behind phosphorus retention and release in the sediment is crucial in order to understand shallow lakes' functioning and determine effective management strategies.

\section{References}

[1] Topçuoğlu, S. (2005) Denizel Biyota Örneklerinde Ağır Metal Kontaminasyonu. Deniz Kirliliği. In: Güven, K.C. and Öztürk, B., Eds., TÜDAV Yayınları, İstanbul, 205-225.

[2] Boyd, C.E. and Tucker, C.S. (1998) Pond Aquaculture Water Quality Management. Kluwer Academic Publishers, 698 p. http://dx.doi.org/10.1007/978-1-4615-5407-3

[3] MacDonald, D.D., Ingersoll, C.G. and Berger, T.A. (2000) Development and Evaluation of Consensus-Based Sediment Quality Guidelines for Freshwater Ecosystems. Archives of Environmental Contamination and Toxicology, 39, $20-31$. http://dx.doi.org/10.1007/s002440010075 
[4] Altındag, A. and Yigit, S. (2005) Assessment of Heavy Metal Concentrations in the Food Web of Lake Beysehir, Turkey. Chemosphere, 60, 552-556.

[5] Kır, I., Ozan Tekin, S. and Tuncay, Y. (2007) Kovada Gölü’nünsu vesedimentindekibazı ağırmetallerin mevsimsel değişimi. EU Journal of Fisheries \& Aquatic Sciences, 24, 155-158.

[6] Mendil, D. and Uluözlü, D.Ö. (2007) Determination of Tracemetal Levels in Sediment and Five Fish Species from Lakes in Tokat, Turkey. Food Chemistry, 101, 739-745. http://dx.doi.org/10.1016/j.foodchem.2006.01.050

[7] Özmen, H., Külahci, F., Cukurovali, A. and Dogru, M. (2004) Concentrations of Heavy Metal and Radio Activity in Surface Water and Sediment of Hazar Lake (Elazig, Turkey). Chemosphere, 55, 401-408. http://dx.doi.org/10.1016/j.chemosphere.2003.11.003

[8] Karadede-Akın, H. (2009) Seasonal Variations of Heavy Metals in Water, Sediments, Pondweed (P. Pectinatus L.) and Freshwaterfish (C. c. umbla) of Lake Hazar. Elazığ-Turkey. Fresenius Environmental Bulletin, 18, 511-518.

[9] Kurun, A., Balkıs, N., Erkan, M., Balkıs, H., Aksu, A. and Erşan, M.S. (2010) Total Metal Levels in Crayfish Astacus leptodactylus (Eschscholtz, 1823), and Surface Sedimentsin Lake Terkos, Turkey. Environmental Monitoring and Assessment, 169, 385-395. http://dx.doi.org/10.1007/s10661-009-1181-5

[10] Dalkıran, N., Karacaoğlu, D., Dere, Ş., Sentürk, E. and Torunoğlu, T. (2006) Factors Affecting the Current Status of a Eutrophic Shallow Lake (Lake Uluabat, Turkey): Relationships between Water Physical and Chemical Variables. Chemical Ecology, 22, 279-298. http://dx.doi.org/10.1080/02757540600856229

[11] Anonymous (2013) http://www.turkiyesulakalanlari.com/sulak-alanlar

[12] Barlas, N., Akbulut, N. and Aydoğan, M. (2005) Assessment of Heavy Metal Residues in the Sediment and Water Samples of Uluabat Lake, Turkey. Bulletin of Environmental Contamination and Toxicology, 74, 286-293. http://dx.doi.org/10.1007/s00128-004-0582-y

[13] Elmacı, A., Teksoy, A., Topaç, O.F., Özengin, N., Kurtoğlu, S. and Başkaya, H.S. (2007) Assessment of Heavy Metals in Lake Uluabat, Turkey. African Journal of Biotechnology, 6, 2236-2244.

[14] Arslan, N., Koç, B. and Çiçek, A. (2010) Metal Contents in Water Sediment and Oligochaeta-Chironomidae of Lake Uluabat a Ramsar Site of Turkey. The Scientific World Journal, 10, 1269-1281. http://dx.doi.org/10.1100/tsw.2010.117

[15] Tekin-Özan, S. and Aktan, N. (2012) Relationship of Heavy Metals in Water, Sediment and Tissues with Total Length, Weight and Seasons of Cyprinus carpio L., 1758 from Işikli Lake (Turkey). Pakistan Journal of Zoology, 44, 14051416.

[16] Tunca, E., Atasagun, S. and Sayg1, Y. (2012) Yeniçağa Gölü’nde (Bolu-TÜRKIYYE) su, sediment ve kerevitteki (Astacus leptodactylus) bazı ağır metallerin birikimi üzerine bir ön çalışma. Ekoloji, 21, 68-76. http://dx.doi.org/10.5053/ekoloji.2012.838

[17] Benzer, S., Arslan, H., Uzel, N., Gül, A. and Y1lmaz, M. (2013) Concentrations of Metals in Water, Sediment and Tissues of Cyprinus carpio L., 1758 from Mogan Lake (Turkey). Iranian Journal of Fisheries Sciences, 2, 45-55.

[18] Başyiğit, B. and Tekin-Özan, S. (2013) Concentrations of Some Heavy Metals in Water, Sediment and Tissues of Pikeperch (Sander lucioperca) from Karataş Lake Related to Physico-Chemical Parameters, Fish Size and Seasons. Polish Journal of Environmental Studies, 22, 633-644.

[19] Dural, M., Goksu, M.Z.L. and Ozak, A.A. (2007) Investigation of Heavy Metal Levels in Economically İmportant Fish Species Captured from the Tuzla Lagoon. Food Chemistry, 102, 415-421. http://dx.doi.org/10.1016/j.foodchem.2006.03.001

[20] Arslan, N., Tokatlı, C., Çiçek, A. and Köse, E. (2011) Determination of Some Metal Concentrations in Water and Sediment Samples in Yedigöller Region (Kütahya). Review of Hydrobiology, 4, 17-28.

[21] Çevik, F., Göksu, L., Derici, B. and Fındık, Ö. (2009) An Assessment of Metal Pollution in Surface Sediments of Seyhan Dam by Using Enrichment Factor, Geoaccumulation İndex and Statistical Analyses. Environmental Monitoring and Assessment, 152, 309-317. http://dx.doi.org/10.1007/s10661-008-0317-3

[22] Uysal, K., Özden, Y., Çiçek, A. and Köse, E. (2010) Bioaccumulation Ratios of Sediment-Bound Heavy Metals of Porsuk and Enne Dam Lakes (Kütahya/Turkey) to Different Tissues of Common Carp (Cyprinus carpio). İstanbul University Journal of Fisheries and Aquatic Sciences, 25, 1-10.

[23] Karadede, H. and Ünlü, E. (2000) Concentrations of Some Heavy Metals in Water, Sediment and Fish Species from the Atatürk Dam Lake (Euphrates), Turkey. Chemosphere, 41, 1371-1376. http://dx.doi.org/10.1016/S0045-6535(99)00563-9

[24] Ural, M., Uysal, K., Çiçek, A., Köse, E., Koçer, M.A.T., Arca, S., Örnekçi, G.N., Demirol, F. and Yüce, S. (2011) Determination of Trace Element Concentraions in Water, Sediment and Fish Species from the Atatürk Dam Lake (Euphrates), Turkey. Fresenius Environmental Bulletin, 20, 2036-2040.

[25] Öztürk, M., Özözen, G., Minareci, O. and Minareci, E. (2008) Determination of Heavy Metals in of Fishes, Water and 
Sediment from the Demirköprü Dam Lake (Turkey). Journal of Applied Biological Sciences, 2, 99-104.

[26] Öztürk, M., Özözen, G., Minareci, O. and Minareci, E. (2009) Determination of Heavy Metals in of Fish, Water and Sediment of Avşar Dam Lake inTurkey. Iranian Journal of Environmental Health Science Engineering, 6, 73-80.

[27] Özdemir, N., Yilmaz, F., Levent Tuna, A. and Demirak, A. (2010) Heavy Metal Concentrations in Fish (Cyprinuscarpio and Carassiuscarassius) Sediment and Water Found in the Geyik Dam Lake, Turkey. Fresenius Environmental Bulletin, 5, 798-804.

[28] Çiçek, A., Tokatlı, C., Emiroğlu, Ö., Köse, E., Başkurt, S. and Sülün, Ş. (2013) Macro and Micro Element Concentrations in Water, Sediment and Commercial Fishes of Çatören Dam (Eskişehir). Journal of Researh in Ecology, 2, 91-99.

[29] Akcay, H., Oguz, A. and Karapire, C. (2003) Study of Heavy Metal Pollution and Speciation in Buyak Menderes and Gediz River Sediments. Water Research, 37, 813-822. http://dx.doi.org/10.1016/S0043-1354(02)00392-5

[30] Dundar, M.S. and Altundag, H. (2007) Investigation of Heavy Metal Contaminations in the Lower Sakarya River Water and Sediments. Environmental Monitoring and Assessment, 128, 177-181. http://dx.doi.org/10.1007/s10661-006-9303-9

[31] Tüzen, M. (2003) Determination of Trace Metals in the River Yeşilırmak Sediments in Tokat, Turkey Using Sequential Extraction Procedure. Microchemical Journal, 74, 105-110. http://dx.doi.org/10.1016/S0026-265X(02)00174-1

[32] Mendil, D., Ünal, Ö.F., Tüzen, M. and Soylak, M. (2010) Determination of Trace Metals in Different Fish Species and Sediments from the River Yeşilırmak in Tokat Turkey. Food and Chemical Toxicology, 48, 1383-1392. http://dx.doi.org/10.1016/j.fct.2010.03.006

[33] Karadede-Akın, H. and Ünlü, E. (2007) Heavy Metal Concentrations in Water, Sediment, Fish and Some Benthic Organisms from Tigris River, Turkey. Environmental Monitoring and Assessment, 131, 323-337. http://dx.doi.org/10.1007/s10661-006-9478-0

[34] Demirak, A., Yilmaz, F., Levent Tuna, A. and Özdemir, N. (2006) Heavy Metals in Water, Sediment and Tissues of Leuciscus cephalus from a Stream in Southwestern Turkey. Chemosphere, 63, 1451-1458. http://dx.doi.org/10.1016/j.chemosphere.2005.09.033

[35] Y1lmaz, F. (2006) Bioaccumulation of Heavy Metals in Water, Sediment, Aquaticplants and Tissues of from Kizilırmak, Turkey. Fresenius Environmental Bulletin, 5, 360-369.

[36] Akbulut, A. and Akbulut, N. (2010) The Study of Heavy Metal Pollution and Accumulation in Water, Sediment, and Fish Tissue in Kizllırmak River Basin in Turkey. Environmental Monitoring and Assessment, 167, 521-526. http://dx.doi.org/10.1007/s10661-009-1069-4

[37] Anonymous (2004) http://www.cygm.gov.tr/CYGM/homepage/regulations

[38] Sondergaard, M., Jensen, J.P. and Jeppesen, E. (2001) Retention and Internal Loading of Phosphorus in Shallow, Eutrophic Lakes. The Scientific World, 1, 427-442. http://dx.doi.org/10.1100/tsw.2001.72

[39] Eckert, W., Didenko, J., Uri, E. and Eldar, D. (2003) Spatial and Temporal Variability of Particulate Phosphorus Fractions in Seston and Sediments of Lake Kinneret under Changing Loading Scenario. Hydrobiologia, 494, $223-229$. http://dx.doi.org/10.1023/A:1025474517703

[40] Shaw, J.F.H. and Prepas, E.E. (1990) Relationships between Phosphorus in Shallow Sediments and in the Trophogenic Zone of Seven Alberta Lakes. Water Resources, 24, 551-556.

[41] Cooke, G.D.,Welch, E.B., Peterson, S. and Newroth, P. (1993) Restoration and Management of Lakes and Reservoirs. 2nd Edition, Lewis Publishers, Boca Raton.

[42] Pulatsü, S., Akçora (Topçu), A. and Köksal, F. (2003) Sediment and Water Phosphorus Characteristics in a Pond of Spring Origin, Sakaryabaş1 Springs Basin, Turkey. Wetlands, 23, 200-204. http://dx.doi.org/10.1672/0277-5212(2003)023[0200:SAWPCI]2.0.CO;2

[43] Pulatsü, S. and Topçu, A. (2006) Sakaryabaşı Batı Göleti’nde (Türkiye) Sedimentten Fosfor Salınımının Tahmini. Ege Üniversitesi Su Ürünleri Fakültesi Dergisi, 23, 119-121.

[44] Topçu, A. and Pulatsü, S. (2014) Phosphorus Fractions and Cycling in the Sediment of a Shallow Eutrophic Pond. Journal of Agricultural Sciences, 20, 63-70.

[45] Topçu, A. and Pulatsü, S. (2011) Sakaryabaşı (Çifteler-Eskişehir) Balık Üretim ve Araştırma İstasyonu'nun Su Kaynağı Batı Göleti: Sediment Kaynaklı İnorganik Azot Salınımının Araştırılması. Ekoloji, 20, 26-33. http://dx.doi.org/10.5053/ekoloji.2011.785

[46] Topçu, A. and Pulatsu, S. (2008) Phosphorus Fractions in Sediment Profiles of the Eutrophic Lake Mogan, Turkey. Fresenius Environmental Bulletin, 17, 164-172.

[47] Pulatsü, S., Topçu, A., Kırkağaç, M. and Köksal, G. (2008) Sediment Phosphorus Characteristics in the Clearwater 
State of Lake Mogan, Turkey. Lakes \& Reservoirs: Research and Management, 13, 197-205. http://dx.doi.org/10.1111/j.1440-1770.2008.00369.x

[48] Pulatsu, S. and Topcu, A. (2009) Seasonal and Vertical Distributions of Porewater Phosphorus and Iron Concentrations in a Macrophyte-Dominated Eutrophic Lake. Journal of Environmental Biology, 30, 801-806.

[49] Gürevin, C., Ertürk, A. and Albay, M. (2013) Comparative Study of Nutrient Release from Sediment of the Küçükçekmece Lagoon under Field and Laboratory Conditions. Proceedings of the 8th Symposium for European Freshwater Sciences, Münster, 1-5 July 2013. 
Scientific Research Publishing (SCIRP) is one of the largest Open Access journal publishers. It is currently publishing more than 200 open access, online, peer-reviewed journals covering a wide range of academic disciplines. SCIRP serves the worldwide academic communities and contributes to the progress and application of science with its publication.

Other selected journals from SCIRP are listed as below. Submit your manuscript to us via either submit@scirp.org or Online Submission Portal.
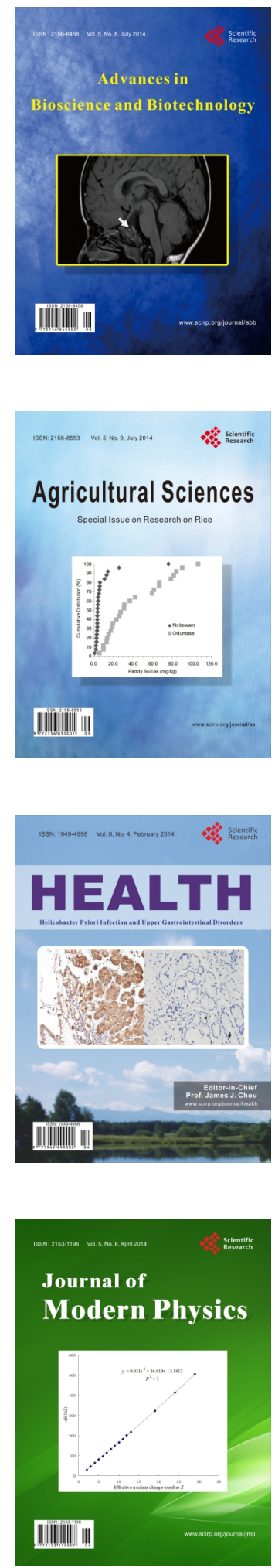
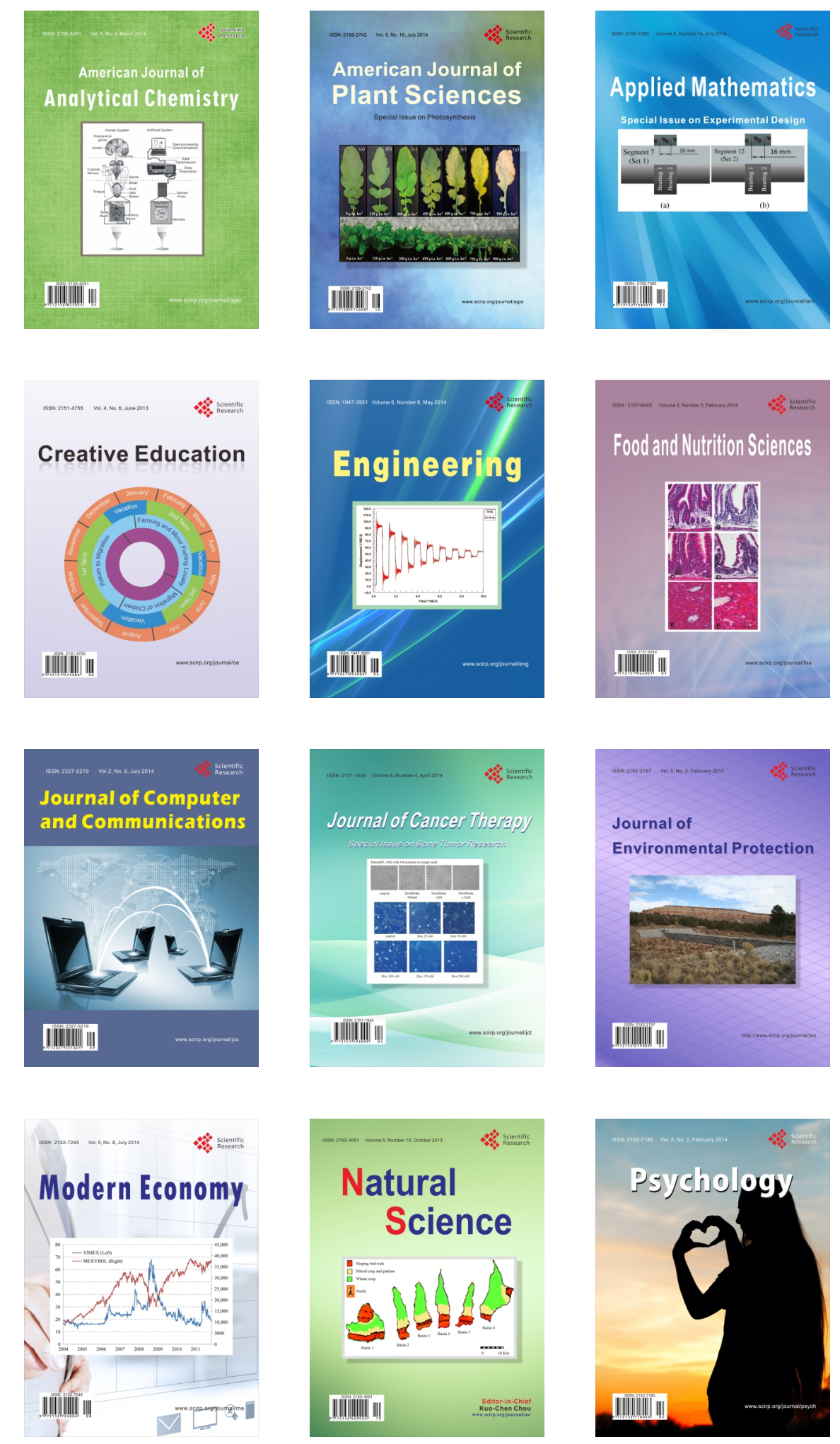